\title{
KONCEPCJA INTELIGENTNEGO ROZWOJU (SMART DEVELOPMENT) - WYZWANIE DLA PLANOWANIA OBSZARÓW WIEJSKICH
}

Zarys treści: Inteligentny rozwój obszarów wiejskich (rural smart development) jest stosunkowo nową koncepcją w polityce społecznej, ekonomicznej i przestrzennej Unii Europejskiej. Działanie to wpisuje się w obecne trendy planowania rozwoju państw i regionów UE. W oparciu o zintegrowane podejścia strategiczne, które odzwierciedlają priorytety UE, a także potrzeby danego terytorium, programy rozwoju obszarów wiejskich wspierają różne działania społeczne w tym zakresie. Aktywność interesariuszy ma na celu dalszą modernizację obszarów wiejskich, w tym inwestycje w infrastrukturę oraz projekty w zakresie łączności cyfrowej oraz budowy oddolnych inicjatyw lokalnych. Koncepcja inteligentnego rozwoju wsi zakłada generowanie procesów innowacji społecznych i ekonomicznych, a tym samym wzmacnianie zasobów terytorialnych. Istota takiego rozwoju opiera się m.in. na modernizacji usług publicznych za pomocą technologii cyfrowych, a także na lepszym wykorzystaniu wiedzy w inicjatywach społecznych i gospodarczych. Technologie cyfrowe i innowacje społeczne prowadzą do wzrostu jakości życia mieszkańców oraz lepszego wykorzystania zasobów terytorialnych (Barca 2009).

Od początku XXI wieku w polityce rozwoju UE, w tym polityce spójności terytorialnej, podkreśla się rolę wiedzy, zakorzenienia, instytucji oraz, co za tym idzie, kultury lokalnej. Zwróciło to uwagę interesariuszy rozwoju regionalnego i lokalnego na taki rodzaj działań i spodziewanych efektów, które odnoszą się wprost do dynamiki miejsc, ich charakteru, zróżnicowania, zmienności, jak również różnej ich odporności/wrażliwości na procesy zachodzące w otoczeniu. Cele polityki przestrzennej, zawarte m.in. w Strategii „Europa 2020”, muszą być zatem na tyle elastyczne, aby można było realizować potrzeby społeczne ludzi zamieszkujących różne obszary wiejskie wspólnoty. W artykule poruszono kwestię genezy koncepcji inteligentnego rozwoju oraz jej wiejskiego kontekstu. Określono również procesy przemian społecznych, które stanowią ogólne płaszczyzny oddziaływania koncepcji inteligentnego rozwoju obszarów wiejskich.

Słowa kluczowe: Obszary wiejskie, rozwój inteligentny, planowanie strategiczne. 


\section{Wprowadzenie}

Inteligentny rozwój obszarów wiejskich (rural smart development) jest stosunkowo nową koncepcją w polityce społeczno-gospodarczej i przestrzennej Unii Europejskiej. Działanie to wpisuje się w obecne trendy planowania rozwoju państw Unii Europejskiej. Polityka rozwoju obszarów wiejskich (EFRROW) wskazuje na obszerny zestaw narzędzi do wspierania rozwoju inteligentnych obszarów wiejskich. W oparciu o zintegrowane podejścia strategiczne, które odzwierciedlają priorytety UE, a także potrzeby danego terytorium, programy rozwoju obszarów wiejskich powinny wspierać różne działania społeczne w tym zakresie. Aktywności te mają na celu dalszą modernizację obszarów wiejskich, w tym inwestycje w małą infrastrukturę i projekty w zakresie komunikacji oraz oddolnych inicjatyw lokalnych, co w konsekwencji ma prowadzić do trwałego (zrównoważonego) rozwoju. Koncepcja inteligentnego rozwoju wsi odnosi się do generowania procesów innowacji społecznych, a tym samym do kształtowania zasobów terytorialnych. Istota takiego rozwoju opiera się m.in. na wzmacnianiu sieci usług publicznych za pomocą technologii cyfrowych, a także na lepszym wykorzystaniu wiedzy w rozwoju społecznym i ekonomicznym. Technologie cyfrowe i innowacje społeczne wspierają wzrost jakości życia, w tym jakość usług publicznych dla mieszkańców oraz lepsze wykorzystanie zasobów terytorialnych (Barca 2009).

Od początku XXI wieku w polityce rozwoju UE, w tym polityce spójności terytorialnej, podkreśla się rolę wiedzy (różnych jej typów), zakorzenienia, instytucji oraz co za tym idzie kultury lokalnej. Zwróciło to uwagę interesariuszy rozwoju regionalnego i lokalnego na taki rodzaj działań i efektów, które odnoszą się wprost do miejsc, ich charakteru, zróżnicowania, zmienności, jak również różnej odporności na procesy zachodzące $\mathrm{w}$ otoczeniu. Polityka wynikająca $\mathrm{z}$ tego nastawienia, zawarta m.in. w Strategii „Europa 2020”, musi być zatem na tyle elastyczna, aby mogła uwzględniać potrzeby społeczne ludzi zamieszkujących zróżnicowane obszary zurbanizowane oraz peryferyjne wspólnoty. W artykule poruszono kwestię genezy koncepcji inteligentnego rozwoju oraz jej wiejskiego kontekstu. Określono również procesy przemian społecznych, które stanowią ogólne płaszczyzny oddziaływania koncepcji inteligentnego rozwoju obszarów wiejskich.

\section{Innowacje w rozwoju wsi. Nowy-stary temat w geografii czlowieka}

Choć różne współczesne koncepcje rozwoju obszarów wiejskich przedstawiane są jako nowe, zwłaszcza w kontekście ewolucji europejskiej polityki rozwoju społeczno-gospodarczego i terytorialnego, to myśl dotycząca relacji ,wiedza-innowacje-przestrzeń" była od zawsze istotna w analizie procesów adaptacyjnych społeczności lokalnych do środowiska. 
Obszerne prace koncepcyjne i empiryczne były udziałem funkcjonalnej szkoły geografii człowieka, którą na przełomie XIX i XX wieku stworzył francuski uczony P. Vidal de la Blache. Ważnym zagadnieniem była koncentracja na relacji człowieka (społeczności) z otoczeniem przyrodniczym i społecznym. Geografia człowieka zwróciła uwagę na związek społeczności rolniczych i otoczenia w kontekście efektów krajobrazowych. Zwolennicy posybilizmu geograficznego podkreślali istotę równowagi pomiędzy trwałością struktur i procesami transformacji. A. Buttimer (1990: 15) twierdziła, że istotą takiego podejścia był dialog pomiędzy milieu - krajobrazem (miejscem jako formą osadnictwa) a civilisation - kulturą, źródłem różnych idei w otoczeniu. „W okresach równowagi, za sprawą pośrednictwa procesów ekologicznych, ani milieu ani civilisation nie były $\mathrm{w}$ pełni elementem zdominowanym lub dominującym. Zmiany w środowisku zewnętrznym często burzyły istniejącą równowagę i rozpoczynały reakcję łańcuchową zmian, dopóki nowa równowaga nie była osiągnięta. Podobnie, związane z civilisation, takie przemiany, jak migracje ludzi bądź idee, nowe środki transportowe czy postęp technologiczny, poprzez redefiniowanie znaczenia przestrzeni i zasobów, były potencjalnymi generatorami nowej równowagi. W ramach każdej cywilizacji współdziałały kreatywne i potencjalne niszczące siły postępu oraz zachowawcze siły tradycji i zwyczaju. Stąd każdą sytuację można było rozpatrywać jako „powstające” lub istniejące napięcie między tym, co utrwalone a innowacją" (Buttimer 1990: 15). Struktura przestrzeni, a tym samym każdego jej elementu, będącego przedmiotem badania, powinna być interpretowana w trzech wymiarach, tj.:

1) wiedzy, która jest częścią sfery kultury (wiedza, idee, wartości);

2) podłoża i wytworów działalności ludzi wraz z organizacją społeczną;

3) przyrody, z którą człowiek wchodzi w relacje.

Przedstawiona wyżej koncepcja jest nieprzemijającym wkładem geografii człowieka w badaniach organizacji społecznej. Innowacje i ich rolę w przemianach społeczno-gospodarczych można rozpatrywać w odniesieniu do tak rozumianej struktury przestrzeni geograficznej.

\section{Zarys koncepcji smart development (inteligentnego rozwoju)}

Koncepcja inteligentnego rozwoju jest jednym z kluczowych elementów europejskiej polityki ekonomicznej zawartej w dokumencie „Europa 2020”, który określa strategiczne działania zmierzające do szybszego wzrostu ekonomicznego powiązanego z redukcją długów publicznych państw oraz nierówności społecznych (zwłaszcza bezrobocia) (European Commission 2010). Ważną kwestią jest rola wiedzy i innowacji, a tym samych znaczenie sektora „badania i rozwój”. W efekcie ma to zwiększyć spójność społeczną, ekonomiczną oraz terytorialną państw i regionów Unii Europejskiej. Priorytety w tym zakresie dotyczą sze- 
rokiego włączenia społecznego $\mathrm{w}$ zakresie korzystania $\mathrm{z}$ nowych technologii (m.in. cyfryzacja), gospodarki cyrkularnej oraz tworzenia miejsc pracy, zwłaszcza na obszarach peryferyjnych. Uwzględnienie roli umiejscowienia (czyli de facto roli geografii) w podejściu do sektorowego ujęcia gospodarki uwydatnia rolę regionu (terytorium) w tworzeniu polityki rozwoju. Dużą rolę w przełożeniu praktyki badawczej na założenia polityki UE miała opracowana dla Komisji Europejskiej przez naukowców, koncepcja inteligentnego rozwoju, jako podstawa kreowania polityki innowacyjności (Foray 2009; Foray i in. 2011).

Problem wdrażania założeń koncepcji inteligentnego rozwoju odnosi się w dużej mierze do specyfiki „miejsca” i zasobów, którymi jest ono obdarzone. Pojęcie „miejsca” jest rozumiane dość szeroko, ale uwaga kierowana jest przede wszystkim na skalę lokalną, co wiąże się z analizą jednostek osadniczych (miast, wsi) lub grup jednostek osadniczych powiązanych relacjami w ramach współpracy terytorialnej. Ten sposób postrzegania zróżnicowania przestrzeni ekonomicznej i społecznej prowadzi do określania specyfiki „miejsca” poprzez wskazanie uwarunkowań dla wystąpienia określonych aktywności gospodarczych, w tym również przyciąganie inwestycji, a wraz z nimi napływ określonych zasobów (Romer 1990; Rauch 1993). Uwagę zwraca się zatem na podatność „miejsca” na wystąpienie określonej innowacji technologicznej czy społecznej, co często jest identyfikowane z podziałami regionów na centralne (metropolitalne) i peryferyjne. Koncepcje odnoszące się do specyfiki „miejsca” akcentują problem poszukiwania takich działań, które można uznać za ich specjalizację. Sprowadza się to do operacjonalizacji pojęcia inteligentnej specjalizacji i opracowania aparatu metodycznego do identyfikacji takich działalności, na których ma się oprzeć strategia dalszego rozwoju (inteligentnego). Wprowadzanie innowacji powinno zatem być ściśle określone ze specjalizacjami tak, aby budować terytorialne przewagi konkurencyjne (Fagerberg i in. 1997; Bilbao-Osorio, Rodrígues-Pose 2004). P. McCann i R. Ortega-Argilés (2015) opisują inteligentną specjalizację w trzech kontekstach, tj.:

1. Zakorzenienie (embeddedness) - przywiązanie działalności podmiotów gospodarczych do terytorium jest oznaką dojrzałości w rozwoju ekonomicznym, kiedy oprócz czynników o charakterze finansowym dużą rolę odgrywają uwarunkowania kulturowe. Dotyczy to w znacznej mierze obszarów wiejskich, gdzie dywersyfikacja ekonomiczna jest mniejsza, a tym samym utrata specjalizacji może być dotkliwa dla całej lokalnej gospodarki. Istotna dla analiz zakorzenienia jest skala badań. Właściwe badanie wpływu specjalizacji na lokalność nie powinno pomijać takich kwestii, jak sąsiedztwo społeczne oraz rodzina.

2. Powiązania i bliskość (relatedness) - są bardzo mocno związane z procesem przekazywania (transferu) wiedzy. Powiązanie ekonomiczne, technologiczne, ale również i społeczne można rozpatrywać w odniesieniu do rozpowszechniania się informacji oraz zbudowanej na nich wiedzy. Istotne jest, jak zauważył 
B. Nooteboom (2000), że informacje są bezużyteczne, jeśli nie są nowe, ale są również bezużyteczne, jeśli są tak nowe, że nie można ich zrozumieć. Wyniki badań pokazują, że istotna jest rola przestrzeni w przekazywaniu wiedzy, tj. odbywa się ona głównie na poziomie lokalnym, a nawet sąsiedzkim, a nie na bardziej zagregowanych poziomach regionalnych (Koster i in. 2014; Andersson i in. 2016).

3. Łączność (connectivity) - istotą tego aspektu jest uwzględnienie usieciowienia jako istotnej cechy życia ekonomicznego i społecznego, zwłaszcza w dobie szybkiego rozwoju nowych technologii. Z jednej strony jest to mobilność człowieka w przestrzeni i łatwość podejmowania decyzji migracyjnych o różnej randze społecznej i przestrzennej, z drugiej zaś to mobilność wirtualna, zdolność do działania w równoległej rzeczywistości (McCann i Ortega-Argilés 2015). W tym zakresie innowacje sprzyjające wzrostowi mobilności pełnią kluczową rolę.

\section{Specyfika budowania strategii smart development dla obszarów wiejskich}

Współczesne koncepcje rozwoju regionalnego w dużej mierze odwołują się do podziału przestrzeni na centra i peryferie. W ujęciu genetycznym często wskazuje się na czynniki związane ze wczesną industrializacją, kiedy wykształciły się innowacyjne centra, które utrzymały przewagę konkurencyjną i dominację ekonomiczną nad pozostałym obszarem regionu, czyli peryferiami (Grosse 2002). Koncepcja rdzenia i peryferii jest często przywoływanym w literaturze modelem rozwoju społeczno-gospodarczego w opisie zróżnicowania terytorialnego zasobów i władzy. Do koncepcji tej badacze odwołują się stosunkowo często, zwłaszcza w kwestiach opisu przestrzennego rozmieszczenia zasobów (mapowanie rozwoju) oraz trwałości tych układów w czasie. Założenia tej teorii służą również do opisu zróżnicowań w różnych skalach - lokalnej i regionalnej (np. koncepcja regionu węzłowego, rozwoju spolaryzowanego), przez krajową (np. koncepcje urbanizacji i metropolizacji, dyfuzji innowacji) po skalę globalną (np. koncepcja systemu światowego).

W przypadku samych obszarów wiejskich zróżnicowanie przestrzeni opisywane jest często w kategoriach wielofunkcyjności. Koncepcja rozwoju wielofunkcyjnego $\mathrm{w}$ dużym stopniu powiela sposób patrzenia na strukturę przestrzenną regionu w kategoriach centrum-peryferie, przy czym ich identyfikacja (centrów i peryferii) odbywa się w obrębie terenów wiejskich (Wójcik 2011). W ten sposób wyróżnia się pewne typy rozwoju wielofunkcyjnego obszarów wiejskich, których struktura funkcjonalna oraz dominacja funkcji podstawowych jest przedstawiana jako pewien wzór przemian, choć identyfikuje się je nie tylko w oparciu o funkcje pozarolnicze, ale również rolnicze (np. funkcje towarowego, efektywnego rolnictwa). Popularność tej koncepcji w różnych odmianach badawczych, np. wiejskich obszarów problemowych (Bański 2006), wiejskich obszarów 
sukcesu (Czapiewski 2010), jest ważnym elementem współczesnej identyfikacji obszarów społeczno-gospodarczego wzrostu i stagnacji na wsi.

W model „rdzeń-peryferia”, w tym również w układ „,wzrost-stagnacja obszarów wiejskich", wpisuje się koncepcja i polityka inteligentnego wzrostu. Przemyślenia w tym zakresie dotyczą prób przełożenia doświadczeń towarzyszących zastosowaniu koncepcji wdrożonych w obszarach metropolitalnych na obszary wiejskie. Pierwsza ważna kwestia wiąże się z pytaniem, czy obszary wiejskie mogą być miejscem nie tylko przyjmowania innowacji, ale również ich powstawania. Problem odnosi się przede wszystkim do wiejskich obszarów peryferyjnych, które w konkurencji o np. inwestycje są dyskryminowane lub pomijane w ogóle (McCann i Ortega-Argilés 2015). L. Naldi i in. (2015) w rozważaniach nad możliwościami realizacji polityki inteligentnego rozwoju wsi zwracają uwagę na następujące uwarunkowania:

1. Procesy aglomeracji - koncentracja działalności gospodarczych jest powiązana z procesami koncentracji ludności i infrastruktury. Procesy aglomeracji sprzyjają pojawianiu się innowacji ekonomicznych i społecznych, tym samym aglomeracje miejskie są centrami ich dyfuzji oraz wiedzy, na której się opierają. Korzyści aglomeracji dotyczą wielu kwestii, m.in. transportu, bliskości firm z tej samej branży (specjalizacja), wyspecjalizowanych usług dla przedsiębiorstw, zasobów kapitału społecznego i wiedzy. W przypadku obszarów wiejskich istotne jest tworzenie lokalnych specjalizacji oraz rozbudowy więzi z obszarami zurbanizowanymi, zwłaszcza w zakresie rozwoju transportu i łączności. Poszukiwanie nisz rynkowych dopasowanych do lokalnych uwarunkowań społecznych oraz, co istotne dla wsi, przyrodniczych może w konsekwencji włączyć obszary wiejskie w obieg informacji i dóbr, a także ludzi, co pociąga za sobą wzrost różnorodności ekonomicznej i społecznej.

2. Kreatywność gospodarki lokalnej - związek kreatywności z procesem tworzenia innowacji jest współcześnie podkreślany w badaniach rozwoju regionalnego i lokalnego. W przypadku obszarów wiejskich kluczową kwestią jest tworzenie uwarunkowań, które pozwolą wygrać konkurencję z innymi obszarami, zwłaszcza metropolitalnymi. Tworzenie udogodnień do przyciągania na obszary wiejskie nowych zasobów - wykształconych pracowników, specjalistów oraz przedsiębiorstw jest procesem długim, ale nie niemożliwym. Czynnikiem podnoszącym w tym zakresie konkurencyjność jest środowisko przyrodnicze. Klasa kreatywna wysoko bowiem ceni sobie pracę w środowisku czystym, estetycznym, a styl życia ludzi łączy ze sobą aspekty kontaktu z naturą oraz elastycznej pracy. Kluczowym elementem jest nieograniczony dostęp do informacji i wiedzy, który zapewnia łączność elektroniczna.

3. Sieci współpracy - dla tworzenia innowacji oraz inteligentnej specjalizacji istotne są sieci wymiany informacji i wiedzy. Przyjęcie wiedzy oraz wytwarzanie nowej jest istotne dla całego procesu postępu w zakresie tworzenia prze- 
wagi konkurencyjnej, zwłaszcza w działalnościach wyspecjalizowanych. Kluczowym warunkiem jest rozwój szybkiego Internetu, zwłaszcza w regionach peryferyjnych, który w największym stopniu odpowiada za przełamywanie barier rozwojowych. Tworzenie sieci współpracy zarówno w zakresie branż o podobnej działalności, jak i w przypadku łańcuchów tworzenia nowych usług i produktów jest jednym z najbardziej pożądanych mechanizmów przekształceń gospodarczych i społecznych. Ważnym elementem jest również zapewnienie świadczenia usług publicznych na wysokim poziomie.

Wszystkie wymienione wyżej uwarunkowania powinny być uwzględniane w planowaniu strategii inteligentnego rozwoju obszarów wiejskich. Decydują one bowiem o charakterze obszaru wiejskiego, a tym samym możliwościach tworzenia i przyjmowania innowacji.

\section{Gentryfikacja obszarów wiejskich w tworzeniu społecznego środowiska dla rozwoju inteligentnych specjalizacji w Polsce}

Od wielu lat, niemal równolegle do badań miejskich, podejmowane są próby określenia istoty (zakresu) gentryfikacji wiejskiej (Philips 2005). Również i w tym przypadku zakres zjawisk opisywanych w kontekście gentryfikacji, lub jako jej przejaw, jest bardzo duży i obejmuje zarówno zjawisko napływu nowych grup społecznych (nie zawsze zamożniejszych, ale np. lepiej wykształconych i poszukujących alternatywnego środowiska życia), jak i odnowę (rewitalizację) infrastruktury oraz inne aspekty rozwoju lokalnego ${ }^{1}$. Ważne jest również to, co opisano wyżej, w różnych politykach dotyczących rozwoju inteligentnych specjalizacji. Zostawiając na uboczu dosłowne traktowanie terminu „gentryfikacja”, warto zastanowić się, które z procesów społeczno-gospodarczych zachodzących w ostatnich latach, zwłaszcza po wejściu Polski do Unii Europejskiej, można określić jako tworzące się społeczne środowisko dla wprowadzania innowacji oraz inteligentnej specjalizacji obszarów wiejskich. Za najbardziej istotne można uznać następujące:

1. Procesy suburbanizacji - stanowią one w dużym stopniu przedłużenie gentryfikacji miejskiej w przestrzeni o odmiennych cechach, np. ekstensywnym użytkowaniu ziemi, dziedzictwie ruralistycznego rozwoju. Procesy te współ-

${ }^{1}$ J. Grzeszczak (2010: 17) argumentuje, że bardzo trudno jest ustalić (wprowadzić) uniwersalną definicję gentryfikacji. Można wydzielić dwie grupy definicji, tj. po pierwsze, odnoszące się do ujęcia ścisłego (restrykcyjnego) i po drugie, do ujęcia szerszego (inkluzywnego). W ujęciu ścisłym gentryfikacja definiowana jest jako działania (procesy) zmierzające do wyparcia mniej zamożnych klas społecznych (robotniczych) przez lepiej sytuowane (głównie klasa średnia). Częściej przyjmowane są definicje inkluzywne, które opisują gentryfikację w kontekście modernizacji różnych fragmentów przestrzeni, gdzie dochodzi do wzmocnienia grup społecznych o lepszym statusie materialnym. 
tworzą obecnie nowy wymiar rozwoju stref podmiejskich dużych miast, których niezmienną cechą jest brak stabilności społeczno-gospodarczej, osadniczej oraz znaczne dysproporcje funkcjonalne, społeczno-kulturowe itd. Gentryfikację w tych warunkach można traktować jako akt masowej ekspansji nowych grup społecznych, a tym samym podłoże do tworzenia się różnorodnego środowiska działalności innowacyjnej i specjalizacji w obszarze przejściowym.

2. Procesy modernizacji rolnictwa - warunkowany w ostatnich latach polityką wspólnotową (UE) i oddziaływaniem instrumentów związanych z finansowaniem przemian $\mathrm{w}$ rolnictwie. Umiejętność korzystania ze środków oraz kształtowanie się grupy dużych, nowoczesnych gospodarstw rolnych, zdolnych do konkurencji z rolnictwem innych państw UE, kształtuje w dużym stopniu nową elitę wiejską na obszarach peryferyjnych. „Uszlachetnianie” wsi w tym zakresie polega na wyodrębnieniu się grupy społeczno-zawodowej o wyższych dochodach (zwłaszcza wobec rolników pracujących w mniejszych gospodarstwach) oraz tworzeniu się lobby, zrzeszeń chroniących interesy grupowe, a tym samym uwzględniania nowych potrzeb w unowocześnianiu działalności rolniczej.

3. Procesy odnowy wsi - związane są w największym stopniu z oddziaływaniem środków unijnych $\mathrm{w}$ ramach pomocy dla obszarów wiejskich (II filar Wspólnej Polityki Rolnej). Gentryfikacja wiejska w tym zakresie związana jest przede wszystkim z wyzwalaniem potencjału działań na rzecz ochrony krajobrazu, zachowań prospołecznościowych, a także rozwoju przedsiębiorczości. „Uszlachetnianie” wsi w tym zakresie polega przede wszystkim na poprawie warunków życia na wsi, a duże znaczenie odgrywa w tym wzrost samoświadomości walorów środowiska zamieszkania, co powinno prowadzić do kreowania nowych pomysłów na współczesną realizację potrzeb społecznych (nowe podejścia do „wiejskości”).

4. Procesy przemian działalności turystycznych i rekreacyjnych - formy działań ludzkich w tym zakresie odnoszą się przede wszystkim do wzmacniania wielofunkcyjności wsi. Głównym przejawem gentryfikacji wsi są jednak zjawiska wytwarzania alternatywnej przestrzeni życia, głównie o charakterze czasowego zamieszkiwania wsi („,drugie domy”), co może prowadzić do zmiany miejsca zamieszkania, zwłaszcza warunkowanej przemianami w zakresie rozprzestrzeniania się nowych technologii (łączność).

5. Procesy deglomeracji przemysłu - gentryfikacja wiejska w tym zakresie polega głównie na specyfice wynikającej ze społecznej treści funkcji produkcyjnych. Związane jest to przede wszystkim z przenoszeniem się wykwalifikowanej kadry pracowniczej, również naukowej, na tereny wiejskie (peryferyjne) i tworzeniem nowych form zamieszkiwania wsi. Dotyczy to 
zwłaszcza dziedzin produkcji, których niezbędnym elementem jest czyste środowisko. Nie bez znaczenia są również dziedziny przemysłu korzystające z zasobów przyrody, ale w nowych formach (nowoczesnych) ich przetwarzania, tzn. nieuciążliwych dla otoczenia.

6. Procesy renaturalizacji - w społecznym sensie łączą się z działaniami grup społecznych, których celem jest ochrona środowiska, a także wykorzystywanie efektów renaturalizacji do realizacji stylów życia, odnoszących się do związku człowieka z przyrodą jako źródła wewnętrznej harmonii (np. ruchy proekologiczne), a także nowych form korzystania z alternatywnych źródeł energii oraz realizacji polityki cyrkularności.

\section{Wnioski końcowe}

Koncepcja inteligentnego rozwoju, zwłaszcza w kontekście planowania obszarów wiejskich jest wyzwaniem, które w najbliższych latach będzie angażowało specjalistów różnych dziedzin sektora badań i rozwoju. Istotą tego podejścia jest określenie w pierwszej kolejności związku z innymi koncepcjami, które były podłożem wprowadzania polityk rozwojowych, głównie w relacji do idei trwałego (zrównoważonego) rozwoju. Ważne jest, by przemyślenia te uwzględniały również różne aspekty badawcze, które były podejmowane w naukach społecznych, w tym w geografii człowieka, w długiej tradycji rozwoju pojęć związanych z zagadnieniami przestrzennymi, środowiskowymi i regionalnymi, czego przykładem są podejścia wywodzące się z posybilizmu geograficznego.

Koncepcja inteligentnego rozwoju wsi musi również w dużym zakresie uwzględniać regionalne i lokalne specyfiki, co w pewnej mierze akcentowane jest w polityce zorientowanej na „miejsce” (place-based policy). Jednak w przypadku obszarów wiejskich czy szerzej peryferyjnych, adaptacja tej koncepcji, a później procesy wdrożeniowe, muszą uwzględniać różnice nie tylko ekonomiczne, ale również kulturowe, a tym samym uwypuklać czynniki, które związane są z lokalnymi formami wiedzy. Wiedza i różne podejście do przyjmowania innowacji będą kluczowe dla opracowania strategii inteligentnego rozwoju obszarów wiejskich oraz ich przemian, opartych na lokalnych zasobach ekonomicznych i społecznych. Analizy możliwości wprowadzania tej koncepcji muszą w szerszym zakresie brać pod uwagę charakterystyki wychodzące poza sferę ilościową, opartą na danych formalnych i kierować się w stronę metodologii jakościowej, która w większym stopniu odpowiada za określenie zdolności adaptacyjnych w układach lokalnych. 


\section{Literatura}

Andersson M., Klaesson J., Larsson J.P., 2016, How local are spatial density externalities? Neighbourhood effects in agglomeration economies, „Regional Studies”, 50: 1082-1095. Bański J., 2006, Geografia polskiej wsi, Państwowe Wydawnictwo Ekonomiczne, Warszawa. Barca F., 2009, An Agenda for a Reformed Cohesion Policy: a Place-based Approach to Meeting European Challenges and Expectations, EERI Research Paper Series 06/2008, Economics and Econometrics Research Institute (EERI), Brussels.

Bilbao-Osorio B., Rodríguez-Pose A., 2004, From R\&D to innovation and economic growth in the EU, „Growth Change”, 35(4): 434-455.

Buttimer A., 1990, Charyzmat $i$ kontekst: wyzwanie, ,Przeglad Zagranicznej Literatury Geograficznej”, 4: 11-28 (tłum. z jęz. ang. I. Sagan: Buttimer A., 1978, Charism and Context: The Challenge of: "La géographie humaine”, [w:] Ley D., Samuels M. (red.), Humanistic Geography, Maaraufa Press, Chicago: 58-76.

Czapiewski K.Ł., 2010, Koncepcja wiejskich obszarów sukcesu społeczno-gospodarczego i ich rozpoznanie $w$ województwie mazowieckim, „Studia Obszarów Wiejskich”, 22, IGiPZ PAN, KOW PTG, Warszawa.

European Commission, 2010, Europe 2020: a European Strategy for Smart, Sustainable and Inclusive Growth, European Commission, Brussels.

Fagerberg J., Verspagen B., Caniéls M., 1997, Technology, growth and unemployment across European regions, „Regional Studies”, 31(5): 457-466.

Foray D., 2009, Understanding “smart specialisation”, [w:] Pontikakis D., Kyriakou D., van Bavel R. (red.), The Question of $R \& D$ Specialisation. Perspectives and Policy Implications, European Communities, Luxembourg: 14-26.

Foray D., David P.A., Hall B.H., 2011, Smart Specialisation: from Academic Idea to Political Instrument, the Surprising Career of a Concept and the Difficulties Involved in its Implementation, MTEI Working Paper 2011-001, Management of Technology \&Entrepreneurship Institute, Lausanne.

Grosse T.G., 2002, Przeglad koncepcji teoretycznych rozwoju regionalnego, „Studia Regionalne i Lokalne", 1(8): 25-48.

Grzeszczak J., 2010, Gentryfikacja osadnictwa, Monografie, 11, IGiPZ PAN, Warszawa.

Koster H.R.A., van Ommeren J., Rietveld P., 2014, Is the sky the limit? High-rise buildings and office rents, „Journal of Economic Geography”, 14(1): 125-153.

McCann P., Ortega-Argilés R., 2015, Smart specialization, regional growth and applications to European Union cohesion policy, „Regional Studies”, 49: 1291-1302.

Naldi L., Nilsson P., Westlund H., Wixe S., 2015, What is smart rural development, ,„Journal of Rural Studies", 40: 90-101.

Nooteboom B., 2000, Learning and Innovation in Organizations and Economies, Oxford University Press, Oxford.

Philips M., 2005, Differential Productions of Rural Gentrifications: Illustrations from North and South Norfolk, „Geoforum”, 36: 477-494.

Rauch J.E., 1993, Productivity gains from geographic concentration of human capital: evidence from the cities, ,Journal of Urban Economics”, 34(3): 380-400. 
Romer P.M., 1990, Endogenous technological change, „Journal of Political Economy”, 98(5): 71-102.

Wójcik M., 2011, Wiejski obszar peryferyjny w koncepcjach geograficznych, „Studia Obszarów Wiejskich", 26: 19-34.

\title{
THE CONCEPT OF "RURAL SMART DEVELOPMENT" - A CHALLENGE FOR RURAL PLANNING
}

\begin{abstract}
The development of rural areas is entering a stage where we are increasingly using the opportunities provided by technology. Its essence is the use of information and knowledge to introduce social and economic innovations. This is important because in the process of overcoming the peripherality of rural regions, the role of technological innovations, especially new ways of communication, is increasingly recognized. The implementation of smart development strategies, including new approaches of rural development, is one of the key challenges facing European and national institutions that are responsible for finding solutions to prevent social marginalization processes. The article discusses the genesis of the concept of smart development and its rural context. The processes of social changes with which technological changes are to be combined are also defined.
\end{abstract}

Keywords: Rural areas, smart development, strategic planning.

Dr hab. Marcin Wójcik, prof. nadzw. UŁ Katedra Geografii Regionalnej i Społecznej Wydział Nauk Geograficznych Uniwersytet Łódzki e-mail: marcin.wojcik@geo.uni.lodz.pl 